\section{MEETING CALENDAR}

\section{Canadian Association of African STUdies}

Canadian Association of African Studies will hold its 2002 annual conference at the University of Toronto, Toronto, Ontario, May 29-June 1, 2002. The theme is "The Global and The Local: Africa in the World and the World in Africa." The following subthemes will be addressed: Health and Society; Migration and Ethnicity; Food and Development; the Politics of Reconstruction; Popular Culture. For further information contact: Secretariat, Linda Theriault, c/o CETASE, Université de Montréal C.P. 6128, Succ. Centre-Ville Montréal, Québec, Canada H3C 3J7; Tel: (514) 343-6569; Fax: (514) 343-7716; Email:caas@cetase.umontreal.ca; Website: www.caas.umontreal.ca.

\section{Rand AfrikaAns University}

The Department of Historical Studies at the Rand Afrikaans University will host a conference on behalf of the South African Historical Society. The conference will be held on June 24-26, 2002. The theme is "Heritage Creation and Research: the Restructuring of Historical Studies in Southern Africa." For further information contact: The Conference Organizer 2002, Historical and Heritage Focus, C/o Department of Historical Studies RAU PO Box 524 Auckland Park 2006; Email: ask@lw.rau.ac.za.

INSTITUTE OF CONTEMPORARY BRITISH HISTORY The Institute of Contemporary British History presents its 16 th summer conference on July 8-10 2002. The theme is "Post-Imperial Britain." Topics to be considered will include: Popular Culture; Film, Television and the Media; Literature and the Fine arts; Travel and Tourism; Sport, Politics and Political culture; the Constitution/Devolution; Religion; Social Policy; Migration; Crime and Policing; National identity and Citizenship; Race, Ethnicity and Multiculturalism; Britain and the Wider World; Education; the Monarchy and Social Hierarchy; the Military; Gender Relations; Historiography; Public Ritual and Civic Culture; the Economy and Economic policy and Science and Medicine. For further information contact: Dr Harriet Jones, ICBH, Institute of Historical Research,Senate House, Malet Street, London WC1E 7HU; Email: hjones@icbh.ac.uk;Website:www.icbh.ac. uk/icbh/callhtml.

\section{UnIVERSITY OF CAPE TOWN}

The Faculty of Humanities of the University of Cape Town will host a multidisciplinary conference on June 3-5, 2002. The theme is "Narrative, Trauma and Memory: Working through the South African Armed Conflicts of the 20th century." The conference will especially focus on the following wars affecting South African society: The Anglo Boer (South African) War of 18991902; the First and Second World Wars; and the "Border Wars" and Liberation Struggle of 1960-1990. For further information contact: Chris van der Merwe (Convenor);Email:cnvdm@beattie.uct.ac.z a; Tel: (021) 650-2315.

\section{THE UNIVERSITY OF WARWICK}

The University of Warwick will host a oneday conference on June 1, 2002. The theme is "Rethinking the Colonizers: British Colonial Elites in the Eighteenth and Nineteenth Centuries." For further information contact: Christer Petley, Graduate Programme in History, University of Warwick, Coventry CV4 7AL, UK; Tel:0779 0831 882; Email:c.j.petley@warwick.ac.uk.

\section{OHIO UNIVERSITY'S INSTITUTE FOR THE} African ChILd

The Institute for the African Child at Ohio University announces its fourth annual conference to be held in Athens, Ohio on April 11-13, 2002. The theme is, "HIV/AIDS and the African Child: Health Challenges, Educational Possibilities." In cooperation with the Institute for the African Child, Ohio University Press will publish a volume related to this conference, edited by Arvind Singhal and Stephen Howard. Prospective publication date is World AIDS Day, 2003. For further information contact: Abdul Lamin, Conference Coordinator, Institute for the African Child, Burson House, Ohio University, Athens, $\mathrm{OH}$ 45701; Email: Iamin@ohio.edu;Website : www.ohiou.edu/Toguna.

\section{EMPLOYMENT OPPORTUNITIES}

\section{UNIVERSITY OF VIRGINIA}

The Corcoran Department of History and the Carter G. Woodson Institute at the University of Virginia is offering a tenure track position starting fall of 2002. The candidate should have knowledge of the history of modern western Africa. The department currently has two other specialists in Africa and seeks complementing experience in the field, as well as interest in contributing to broader intellectual and curricu- lum plans in both History and African/African-American Studies. Applicants should send four copies of a vita (including a current e-mail address), a letter describing relevant experience and plans, and the names of three possible referees to: Chair, Africa Search, Department of History, Randall Hall, Charlottesville 22903-4180.

\section{FELLOWSHIPSIAWARDS}

\section{Augsburg College}

The Center for Global Education at Augsburg College announces its Fall 2002 program in Namibia. This program will focus on, "Multicultural Societies in Transition: Southern African Perspectives." The program runs from September 2December 13, 2002. The Spring semester program in Namibia focuses on "Nation Building, Globalization and Decolonizing the Mind." The program runs from January 27 - May 9, 2003. Both programs combine experiential education with rigorous academic work. Students will participate in rural and urban homestays, travel to South Africa and learn from a variety of guest lecturers and field trips. The deadlines are: April 1, 2002 for the fall program and October 15, 2002 for the spring program. For further information or an application form, contact: The Center for Global Education at Augsburg College, Tel: (800) 299-8889; Email: globaled@augsburg.edu; Website: www.augsburg.edu/global.

\section{RECENT DOCTORAL DISSERTATIONS}

Compiled by Joseph J. Lauer of Michigan State University.

The U.S. and Canadian theses listed below were reported in Dissertation Abstracts International (DAl), vol. 61, nos. 10-12 and vol. 62, nos. 1-2 (Aug. 2001). Each citation ends with the order number, if any. American and Canadian theses are usually available from Proquest (formerly University Microfilms International; at PO Box 1346, Ann Arbor, MI 48106-1346). See DAl for abstracts and other details. This is the 52th quarterly supplement to American and Canadian Doctoral Dissertations and Master's Theses on Africa, 1974-1987 (ASA/Crossroads Press, 1989).

\section{AgRiculture}

Bailey, Brent. Social and economic impacts of wild harvested products [Ghana]. Ph.D., West Virginia U., 1999. 9967216.

Conroy, Andrew Bernard. Maasai oxen, agri- 